\title{
The Effect of Sex on the Azoxymethane/Dextran Sulfate Sodium-treated Mice Model of Colon Cancer
}

\section{Sun Min Lee ${ }^{1}$, Nayoung Kim ${ }^{1,2}$, Hee Jin Son ${ }^{3}$, Ji Hyun Park ${ }^{2}$, Ryoung Hee Nam ${ }^{1}$, Min Hee Ham¹, Daeun Choi ${ }^{1}$, Sung Hwa Sohn ${ }^{1}$, Eun Shin ${ }^{4}$, Young-Jae Hwang ${ }^{1}$, Jihee Sung ${ }^{1}$, Dong Ho Lee ${ }^{1}$, Ha-Na Lee ${ }^{5}$}

${ }^{1}$ Department of Internal Medicine, Seoul National University Bundang Hospital, Seongnam, ${ }^{2}$ Department of Internal Medicine and Liver Research Institute, Seoul National University College of Medicine, ${ }^{3}$ Seoul National University College of Medicine, Seoul, ${ }^{4}$ Department of Pathology, Seoul National University Bundang Hospital, Seongnam, Korea, ${ }^{5}$ Receptor Cell Biology Section, Laboratory of Immunogenetics, National Institute of Allergy and Infectious Diseases, NIH, Rockville, MD 20852, USA

Background: The colitis-associated cancer exhibits different characteristics according to sex in the initiation and progression of the tumors. The aim of this study was to investigate the sex-associated difference in the azoxymethane/dextran sulfate sodium (AOM/DSS)-induced colitis-associated cancer model.

Methods: The AOM/DSS ICR mouse model was established to compare male with female, and then the severity of colitis-associated carcinogenesis was examined macroscopically and histologically regarding the number, size, and location of tumors. Subsequently, levels of colonic mucosal cytokine, interleukin (IL)-1 $\beta$ and myeloperoxidase (MPO) were assessed.

Results: At the 16th week, the tumor multiplicity and the pro-inflammatory factors differed according to sex. The total tumor number was significantly higher in male $(P=0.020)$ and the number of large tumors (diameter $>2 \mathrm{~mm}$ ) was higher in male $(P=0.026)$. In male, the tumors located more in distal colon $(P=0.001)$. MPO was significantly higher in AOM/DSS-treated male mice compared to the control group $(P=0.003)$, whereas the corresponding female group showed no significant change $(P=0.086)$. Colonic IL-1 $\beta$ level significantly increased in AOM/DSS groups compared to control groups both in male and female (male, $P=0.014 ;$ female, $P=0.005$ ). It was higher in male group; however, there was no statistical significance $(P=0.226)$.

Conclusions: In AOM/DSS murine model, colitis-associated colon tumorigenesis are induced more severely in male mice than female probably by way of inflammatory mediators such as IL-1 $\beta$ and MPO. The sex-related differences at the animal model of colon cancer suggest the importance of approach to disease with sex-specific medicine in human.

(J Cancer Prev 2016;21:271-278)

Key Words: Sex, Disease models, animal, Colitis, Colonic neoplasms

\section{INTRODUCTION}

Colitis-associated carcinogenesis ranks the third most frequently diagnosed cancers worldwide ${ }^{1}$ and the major cause of death in women with age above 65 years old in Korea and Japan., ${ }^{2.3}$ The gender difference in the prevalence of colorectal cancer is the universal phenomenon, not restricted to specific area or races. ${ }^{1}$ The prevalence of advanced colorectal neoplasms is higher among men than women; cross-sectional analyses estimated that men reach an equivalent prevalence at a much younger age than women. ${ }^{4}$ The tumor location also differs according to gender; women are more frequently diagnosed of the cancer in the right-sided colon. ${ }^{5}$ The tumors in the right-sided colon are associated with microsatellite instability (MSI)-positive and/or CpG island methylator phenotype (CIMP)-positive tumors, known as the more aggressive type than those with chromosomal

Received October 25, 2016, Accepted November 26, 2016

Correspondence to: Nayoung Kim

Department of Internal Medicine, Seoul National University Bundang Hospital, 82 Gumi-ro 173beon-gil, Bundang-gu, Seongnam 13620, Korea Tel: +82-31-787-7008, Fax: +82-31-787-4051, E-mail: nayoungkim49@empas.com, ORCID: Nayoung Kim, http://orcid.org/0000-0002-9397-0406

Copyright (C) 2016 Korean Society of Cancer Prevention

(c) This is an Open Access article distributed under the terms of the Creative Commons Attribution Non-Commercial License (http://creativecommons.org/licenses/by-nc/4.0) which permits unrestricted non-commercial use, distribution, and reproduction in any medium, provided the original work is properly cited. 
instability, which may explain the short-period progression in women. ${ }^{5}$ Therefore, it is recommended for scientific researches to consider sex-associated differences in colitis-associated carcinogenesis.

Colitis-associated cancer is a type of cancer that occurred as a complication of long-term chronic bowel inflammation such as the Crohn's disease and ulcerative colitis. ${ }^{6}$ Chronic inflammatory environments drive cells to malignant transformation to promote tumorigenesis by oxidative stress and the pro-inflammatory factors such as interleukin (IL)-6, IL-1 $\beta$, TNF- $\alpha$ and myeloperoxidase (MPO) ${ }^{7-10}$ However, these factors are no information regarding sex-associated differences in colitis-associated cancer.

Experimental animal models can imitate many characteristics of colon cancer, and they are important in studying the underlying mechanisms of the initiation and progression of colon cancers. ${ }^{11}$ For the mimic of colitis-associated colon tumorigenesis, mice were injected with the carcinogen azoxymethane $(\mathrm{AOM})$ and subsequently treated with the pro-inflammatory agent dextran sulfate sodium (DSS) to develop numerous tumors. ${ }^{12-14}$ The treatment of AOM prevents the resolution of DSS-induced inflammation and promotes dysplasia and hyperplasia. ${ }^{15}$ Tumor growth in AOM/DSS model is directly influenced by the associated inflammatory process. In this model, the development of adequate tumor is confirmed in several mouse strains within 20 weeks. ${ }^{13,16}$

Hence we investigated the effect of sex-associated differences on AOM/DSS-induced colitis-associated carcinogenesis model.

\section{MATERIALS AND METHODS}

\section{Animals}

Four-week-old male and female ICR mice (Orient Co., Ltd., Seoul, Korea) were used for the experiments. Every mouse was housed in cages maintained at $23^{\circ} \mathrm{C}$ with a $12 / 12$-hour light/dark cycle under specific pathogen-free conditions. All experimental procedures were approved by the Institutional Animal Care and

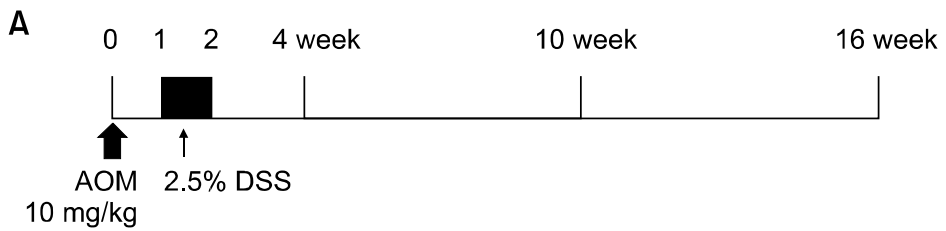

B

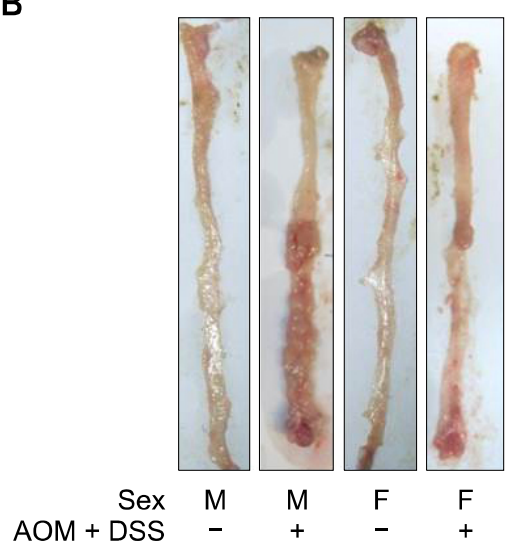

C

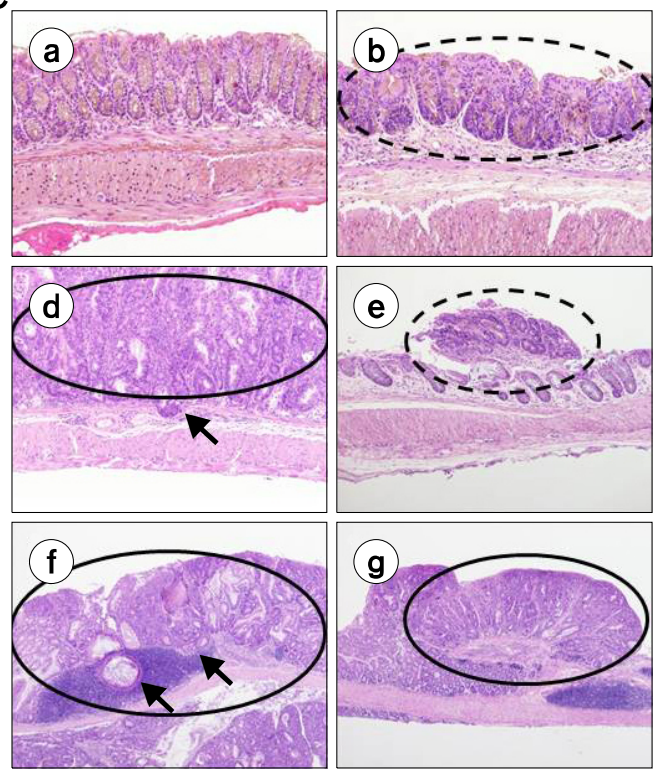

\section{(c)} 4.

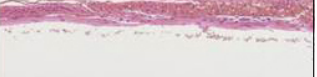

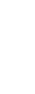


Use Committee of Seoul National University Bundang Hospital (BA1310-139/091-01). The procedures were in accordance with the ARRIVE (Animals in Research: Reporting In Vivo Experiments) statement.

\section{Experimental design}

Experimental groups were consisted of the following 12 groups: group 1-4 sacrificed at the fourth week; group 5-8 sacrificed at the 10th week; and group 9-12 sacrificed at the 16th week: group 1, 5, 9 (male control, $\mathrm{n}=5$, respectively); group 2, 6, 10 (male treated with AOM and DSS, $n=10$, respectively); group 3, 7, 11 (female control, $\mathrm{n}=5$, respectively); group 4, 8, 12 (female treated with AOM and DSS, $n=10$, respectively). Mice in groups
2, 4, 6, 8, 10, and 12 were treated of a carcinogen, AOM (Sigma-Aldrich, St. Louis, MO, USA) by intraperitoneal injection at a concentration of $10 \mathrm{mg} / \mathrm{kg}$ at Day 0 in the experimental schedule (Fig. 1A). For induction of colitis, $2.5 \%$ (w/v) of DSS (MP Biomedicals, Aurora, $\mathrm{OH}, \mathrm{USA}$ ) was supplied in drinking water for seven days after one week from the injection of $\mathrm{AOM}^{17}$ Animals were euthanized by $\mathrm{CO}_{2}$ asphyxiation at 4,10 , and 16 weeks after the injection.

\section{Macroscopic evaluation of tumor incidence and multiplicity}

After the extracting the colons (from cecum to rectum), we opened them longitudinally and washed out the stools with PBS.

Table 1. Incidence and multiplicity of adenoma and cancer in colon

\begin{tabular}{|c|c|c|c|c|c|}
\hline Group & $\begin{array}{l}\text { Adenoma } \\
\text { incidence }\end{array}$ & $\begin{array}{c}\text { Cancer } \\
\text { incidence }\end{array}$ & $\begin{array}{c}\text { Adenoma/cancer } \\
\text { incidence }\end{array}$ & $\begin{array}{c}\text { Adenoma/cancer } \\
\text { multiplicity }\end{array}$ & $\begin{array}{l}\text { Depth of } \\
\text { invasion }\end{array}$ \\
\hline \multicolumn{6}{|l|}{ 4-week male } \\
\hline Control $(n=4)$ & $0.0(0 / 4)$ & $0.0(0 / 4)$ & $0.0(0 / 4)$ & 0.0 & \\
\hline AOM/DSS $(n=6)$ & $50.0(3 / 6)$ & $0.0(0 / 6)$ & $50.0(3 / 6)$ & $0.67 \pm 0.42$ & $\begin{array}{l}\text { Mucosa (0) } \\
\text { Submucosa }(0)\end{array}$ \\
\hline$P$-value ${ }^{\mathrm{a}}$ & 0.200 & 1.000 & 1.000 & & \\
\hline \multicolumn{6}{|l|}{ 4-week female } \\
\hline Control $(\mathrm{n}=5)$ & $0.0(0 / 5)$ & $0.0(0 / 5)$ & $0.0(0 / 5)$ & 0.0 & \\
\hline AOM/DSS $(n=6)$ & $16.7(1 / 6)$ & $0.0(0 / 6)$ & $16.7(1 / 6)$ & $0.17 \pm 0.17$ & $\begin{array}{l}\text { Mucosa }(0) \\
\text { Submucosa }(0)\end{array}$ \\
\hline$P$-value ${ }^{\mathrm{a}}$ & 1.000 & 1.000 & 1.000 & & \\
\hline$P$-value ${ }^{\mathrm{b}}$ & & & & 0.138 & \\
\hline \multicolumn{6}{|l|}{ 10-week male } \\
\hline Control $(\mathrm{n}=5)$ & $0.0(0 / 5)$ & $0.0(0 / 5)$ & $0.0(0 / 5)$ & 0.0 & \\
\hline AOM/DSS $(n=10)$ & $0.0(0 / 10)$ & $70.0(7 / 10)$ & $70.0(7 / 10)$ & $4.90 \pm 0.87$ & $\begin{array}{l}\text { Mucosa (6) } \\
\text { Submucosa }\end{array}$ \\
\hline$P$-value ${ }^{\mathrm{a}}$ & 1.000 & $0.026 *$ & $0.026 *$ & & \\
\hline \multicolumn{6}{|l|}{ 10-week female } \\
\hline Control $(\mathrm{n}=5)$ & $0.0(0 / 5)$ & $0.0(0 / 5)$ & $0.0(0 / 5)$ & 0.0 & \\
\hline AOM/DSS $(n=10)$ & $10.0(1 / 10)$ & $50.0(5 / 10)$ & $60.0(6 / 10)$ & $3.50 \pm 1.40$ & $\begin{array}{l}\text { Mucosa (5) } \\
\text { Submucosa (0) }\end{array}$ \\
\hline$P$-value ${ }^{\mathrm{a}}$ & 1.000 & 0.101 & $0.044 *$ & & \\
\hline$P$-value ${ }^{\mathrm{b}}$ & & & & 0.235 & \\
\hline \multicolumn{6}{|l|}{ 16-week male } \\
\hline Control $(\mathrm{n}=5)$ & $0.0(0 / 5)$ & $0.0(0 / 5)$ & $0.0(0 / 5)$ & 0.0 & \\
\hline AOM/DSS $(n=10)$ & $0.0(0 / 10)$ & $60.0(6 / 10)$ & $60.0(6 / 10)$ & $8.30 \pm 1.98$ & $\begin{array}{l}\text { Mucosa (4) } \\
\text { Submucosa (2) }\end{array}$ \\
\hline$P$-value ${ }^{\mathrm{a}}$ & 1.000 & $0.044 *$ & $0.044 *$ & & \\
\hline \multicolumn{6}{|l|}{ 16-week female } \\
\hline Control $(\mathrm{n}=5)$ & $0.0(0 / 5)$ & $0.0(0 / 5)$ & $0.0(0 / 5)$ & 0.0 & \\
\hline AOM/DSS $(n=10)$ & $0.0(0 / 10)$ & $60.0(6 / 10)$ & $60.0(6 / 10)$ & $3.00 \pm 0.54$ & $\begin{array}{l}\text { Mucosa (4) } \\
\text { Submucosa (2) }\end{array}$ \\
\hline$P$-value ${ }^{\mathrm{a}}$ & 1.000 & $0.044 *$ & $0.044 *$ & & \\
\hline$P$-value ${ }^{\mathrm{b}}$ & & & & $0.020 *$ & \\
\hline
\end{tabular}

Values are presented as $\%$ (number/subtotal), mean \pm SE, or (number) only. AOM, azoxymethane; DSS, dextran sulfate sodium. ${ }^{\mathrm{a} B e t w e e n}$ control and AOM/DSS group. Fisher's exact test. ${ }^{b}$ Between AOM/DSS male and female. Mann-Whitney test. *Asterisk means statistical significance $(P<0.05)$. 
Polypoid lesions under or above $2 \mathrm{~mm}$ in diameter were counted by three gastroenterologists in a blinded manner. Tumor multiplicity was defined as the number of gross polyps approved by the three gastroenterologists.

\section{Histopathology}

The colonic segments containing any grossly proven polyps were fixed with phosphate-buffered formalin and were stained with hematoxylin and eosin (H\&E). The classification of adenoma and adenocarcinoma was performed according to Hamilton and Aaltonen. ${ }^{18}$ Additionally, the depth of invasion by adenocarcinoma in the colonic tissues was specified as mucosa and 'into the submucosa and muscularis'. The tumor incidence was evaluated as the percentage of rats with tumor.

\section{Measurement of the level of cytokines}

The amount of MPO and IL-1 $\beta$ in the colonic tissues was examined by ELISA using the appropriate kits (R\&D systems, Minneapolis, MN, USA). Every assay was performed in triplicate.

\section{Statistical analysis}

Data were expressed as mean \pm SEM. Statistical significance was examined with Mann-Whitney test or Fisher's exact test. $P<$ 0.05 was considered to indicate a statistical significance. All statistical analyses were conducted using PASW Statistics ver. 18.0 (IBM Co., Armonk, NY, USA) software.

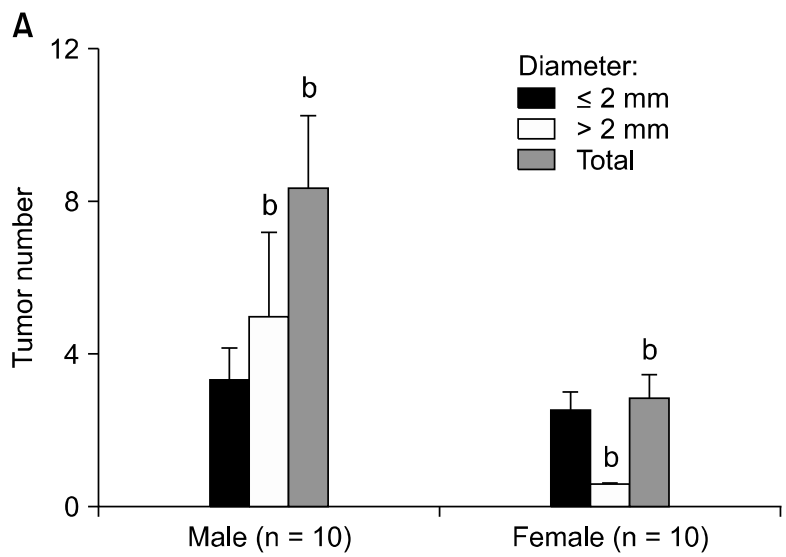

\section{RESULTS}

\section{Incidence of colon adenoma and cancer induced with azoxymethane/dextran sulfate sodium}

The disease status of mouse colon was observed at week 2, 4, 10 , and 16 . In the macroscopic view, there were multiple polyps with big size in male colons while there were several small polyps in female colons (Fig. 1B). To compare them in detail, the incidence and the multiplicity of tumors were evaluated macroscopically, and the tumors were classified by histological analysis (Table 1). At the fourth week, 50.0\% (3/6) of male and $16.7 \%(1 / 6)$ of female mice had adenoma; and none of them had cancer. At the 10th week, the incidence rate of cancer in male was $70.0 \%(7 / 10)$ which was significantly different from that of the control group $(P=0.026)$. In female, adenoma occurred in $10.0 \%(1 / 10)$ and cancer appeared in 50.0\% (5/10). There was no statistical significance in the change of each incidence rate $(P=1.000$ for adenoma and 0.101 for cancer); however, the total incidence including adenoma and cancer was significantly increased $(P=$ 0.044). At this time point, the submucosal invasion was observed in male. At the 16th week, the incidence rate was same in male and female; $60.0 \%(6 / 10)$ of male and female mice had cancer $(P=$ 0.044). In both male and female mice, four out of six had mucosal invasion and two had submucosal invasion of tumor. However, at this time point, the tumor multiplicity of male was higher than female $(8.30 \pm 1.98$ vs. $3.00 \pm 0.54, P=0.020)$. Figure $1 \mathrm{C}$ shows the representative images of the incidence of tumor confirmed with histological analysis, displaying the time-dependent progression of adenoma and adenocarcinoma. In male, there was low grade adenoma at the fourth week, adenocarcinoma with focal

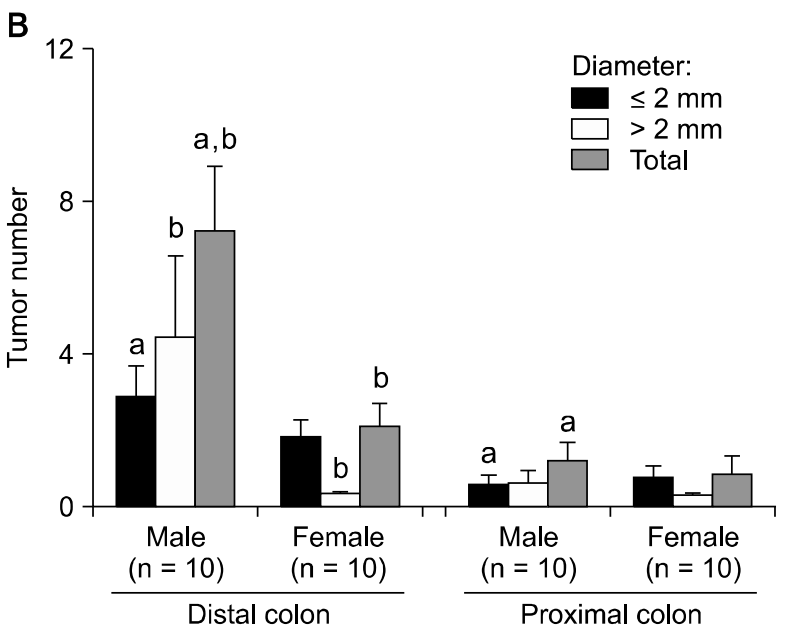

Figure 2. Tumor number according to (A) sex and (B) the colonic location. Data were expressed as mean \pm SE. ${ }^{a} P<0.05$ comparing distal and proximal; ${ }^{\mathrm{b}} P<0.05$ comparing male and female. 
submucosal invasion at the 10th week, and adenocarcinoma with submucosal invasion at the 16 th week.

\section{The tumor multiplicity differed according to the sex}

Since the tumor multiplicity at the 16th week was significantly different depending on the sex, it was analyzed in detail by the number of tumors under or above $2 \mathrm{~mm}$ in diameter. The number of small tumors with diameter under $2 \mathrm{~mm}$ was similar between male and female ( $P=0.646$ ) (Fig. 2A); however, that of massive tumors of diameter above $2 \mathrm{~mm}$ was significantly higher in male than female $(P=0.026)$. According to the location of tumor, in male, tumors smaller than $2 \mathrm{~mm}$ in diameter were distributed more in the distal colon than the proximal colon $(P=0.035)$ (Fig. 2B). The number of tumors larger than $2 \mathrm{~mm}$ in diameter was also relatively higher in male but there was no statistical significance $(P=0.099)$. Overall, in male, there were more tumors in distal colon $(P=0.001)$. In female, on the other hand, there was no significant difference in the distribution of tumors $(P=0.069$ in smaller tumors, 0.615 in larger tumors than $2 \mathrm{~mm}$ in diameter, and 0.094 in total tumors).

\section{Regulation of inflammatory cytokines}

Increase of pro-inflammatory cytokine production is an important factor in the incidence of colorectal tumors. Therefore, following the evaluation of incidence of colon adenoma and cancer, we investigated on the expression of inflammatory cytokines in the colonic tissues. At the fourth week, the MPO was up-regulated in AOM/DSS-treated mice especially in female, which implies the activation of inflammation response (male,
$P=0.086$; female, $P=0.014$ ) (Fig. 3A). The level of IL-1 $\beta$ was also relatively higher in AOM/DSS group, but there was no statistical significance (male, $P=0.055$; female, $P=0.144$ ) (Fig. 3B). At the 10 th week, the IL-1 $\beta$ level of male control mice was significantly incremented compared to that of the fourth week $(P=0.016)$ while that of the female control mice remained similar $(P=$ 0.917) (Fig. 3B). Besides, the level of MPO was also relatively higher in male control with no statistical significance $(P=0.076)$ (Fig. 3A). The reason of the increase of pro-inflammatory cytokines in control male mice has not been determined yet. At the 16th week, MPO was significantly increased compared to the fourth week ( $P=0.027)$; and it was significantly higher in AOM/DSS-treated male mice compared to the control group ( $P=$ 0.003), whereas the corresponding female group showed no significant change (Comparison with the fourth week, $P=0.157$; comparison with control group, $P=0.086$ ) (Fig. 3A). This implies that the up-regulation of MPO was more activated in male than in female. The IL-1 $\beta$ level significantly increased in male and female AOM/DSS groups compared to control groups at the 16th week (male, $P=0.014$; female, $P=0.005$ ) (Fig. 3B). The level was relatively higher in male; however, there was no statistical significance $(P=0.226)$.

\section{DISCUSSION}

In the present study, we observed that the time point of tumor incidence was earlier in male and that the total tumor number was significantly higher in male. According to the location, in male, the tumors were induced mostly in distal colon. At the same
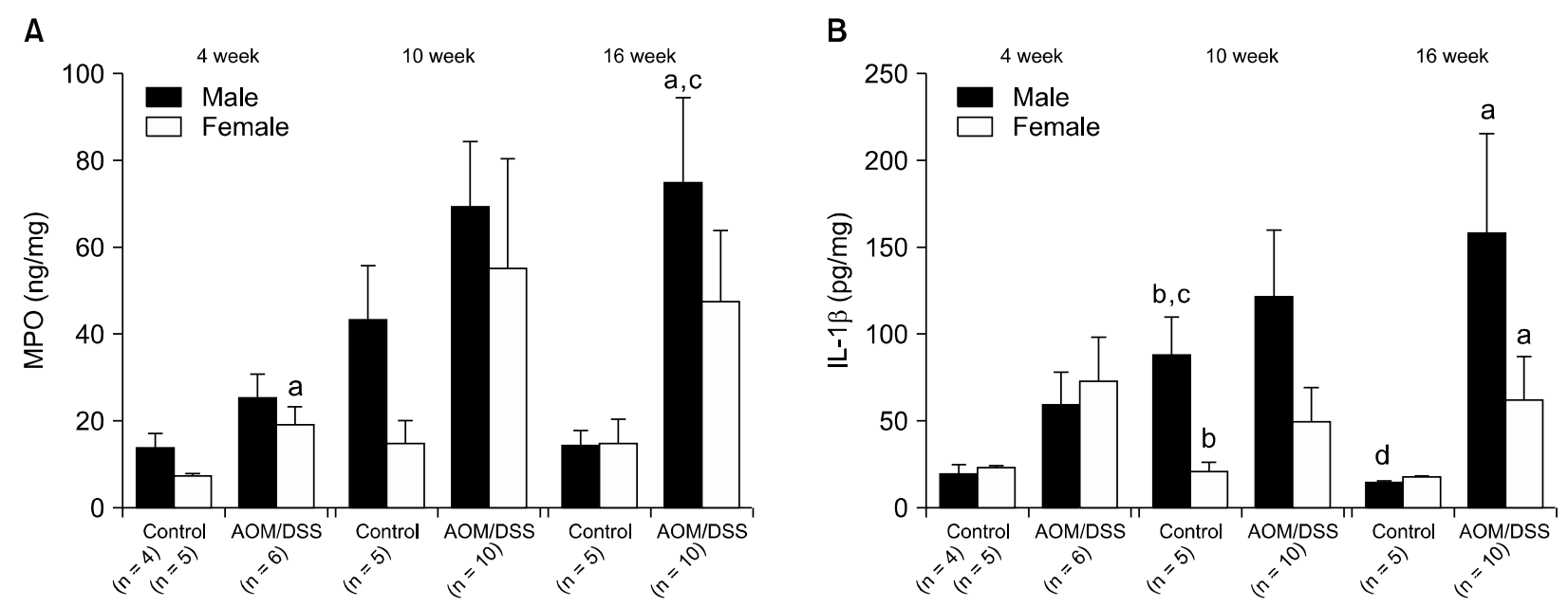

Figure 3. The levels of (A) myeloperoxidase (MPO) and (B) interleukin (IL)-1 $\beta$ in colonic mucosa measured with ELISA. Data were described as mean \pm SE. ${ }^{\mathrm{a}} P<0.05$ comparing control and azoxymethane/dextran sulfate sodium (AOM/DSS); ${ }^{\mathrm{b}} P<0.05$ comparing male and female; ${ }^{\mathrm{c}} P<0.05$ compared to week $4 ;{ }^{\mathrm{d}} P<0.05$ comparing week 10 and 16. 
period, there was submucosal invasion in male. The pro-inflammatory cytokines (IL-1 $\beta$ and MPO) were up-regulated in both male and female mice due to AOM/DSS. In addition, IL-1 $\beta$ expression was also higher in male at 10th week in control.

Treating mice with AOM and DSS is a rapid and effective method for modeling human colitis-associated cancer. Using this model, the involvement of heritable factors can be studied by applying the AOM/DSS on genetically engineered mice. ${ }^{19,20}$ Also AOM/DSS model using wild-type mice can be applied in the research of the impact of pharmacologic target substances in colitis-associated cancer. However, little is known about the sex-associated discrepancies in this animal model. The current protocol reports that sex and age-matched mice may be used, the results using the female mice tended to be more consistent. ${ }^{21,22}$ As seen in this study, the biological response to the AOM and DSS was different depending on the sex, showing analogous aspects with the colon cancer in human.

The colitis-associated cancer is the cancer type preceded by the inflammatory bowel diseases (IBD). ${ }^{6}$ Epidemiologically, the predominance of IBD in women is not generally appeared; it greatly differs according to the geographic regions. ${ }^{23}$ In Asian populations, the IBD was rather consistently predominant in men; ${ }^{2427}$ on the other hand, in European and North-American populations, it ranged from equal distribution to female predominance. ${ }^{28.36}$ Although the underlying mechanisms of gender differences in immune reactions are still unclear, the men are featured with more vulnerability to microbial infections, and women seems to be associated with autoimmunity. ${ }^{37-39}$ The risk of colon cancer as the long-term complication was consistently higher in male IBD patients, according to a meta-analysis of population-based cohort studies. ${ }^{40}$ Also the male IBD patients had increased mortality from colon cancer in a recently published meta-analysis. $^{41}$

In human, there are sex-related biological differences in the colon cancer risk. ${ }^{42}$ In a recent systemic review, it has been reported that a higher proportion of women were diagnosed with cancer in right-sided colon than men. ${ }^{43}$ Also a major cohort study comparing the right-sided and left-sided colon cancer in 17,641 subjects also revealed the association of right-sided colon cancer and women. ${ }^{44}$ In our results, the tumors located more in distal colon, which was consistent with the tendency in human.

The molecular characteristics of colon cancer exhibit discrepancies according to the tumor location, consequently depending on the sex. The left-sided colon cancer more frequently presents chromosomal instability which is related with $60 \%$ to $70 \%$ of colon cancer. ${ }^{45-47}$ On the other hand, the right-sided colon cancer is associated with high MSI, CIMP, and BRAF mutation. ${ }^{46,47}$ The sex-related discrepancies in AOM/DSS model imply the possibility that the molecular features in murine colon may resemble that of humans.

Several evidences have reported the involvement of estrogen on the sex-associated differences in the colon cancer. A population-based case-control study ( $n=4,246)$ suggested the protective impact of estrogen against MSI, and also reported that older women lacking estrogen had incremented risk of the colon cancer with high level of $\mathrm{MSI} .^{48}$ The hormonal replacement therapy is known to decrease the risk of unstable tumors, ${ }^{48}$ and also it was reported by the Women's Health Initiative Clinical Trial to reduce the risk of colon cancer by $40 \%$ in postmenopausal women. ${ }^{49}$ Therefore, further investigations are suggested to study on the hormonal impacts by analyzing the effect of estrogen in male AOM/DSS model.

This study has several limitations. First, the measurement of pro-inflammatory factors was restricted to MPO and IL-1 $\beta$. Investigations on the other cytokines are needed to figure out the mechanisms of the sex-related differences. Second, the distribution of tumor in female mice was incompletely analyzed because the tumor incidence was not sufficient at the end point (the 16th week). Long-term studies over 16 weeks may be helpful to confirm the tumor-incidence patterns according to locations in female mice.

Although the accumulating evidences have revealed the gender differences, the current screening guidelines for the colon cancer generally do not apply the gender-specific recommendations. The most commonly used colon cancer screening test, the fecal occult blood test is revealed to have different sensitivity by gender. ${ }^{50}$ The diminished gender-specificity of the screening tools may be the reason of a higher mortality and shorter 5-year survival rate of women.

In conclusion, the inflammation-associated cancer was induced earlier and more severely in AOM/DSS-treated male than female mice by way of inflammatory mediators such as IL- $1 \beta$ and MPO. Thus, the sex-related differences at the animal model of colon cancer suggest the importance of approach to disease with sex-specific medicine in human.

\section{ACKNOWLEDGMENTS}

This work was supported by the National Research Foundation (NRF) of Korea funded by the Ministry of Science, ICT and Future Planning (No. NRF-2016R1A2B4013133). 


\section{CONFLICTS OF INTEREST}

No potential conflicts of interest were disclosed.

\section{REFERENCES}

1. Ferlay J, Shin HR, Bray F, Forman D, Mathers C, Parkin DM. Estimates of worldwide burden of cancer in 2008: GLOBOCAN 2008. Int J Cancer 2010;127:2893-917.

2. Jung KW, Park S, Kong HJ, Won YJ, Lee JY, Seo HG, et al. Cancer statistics in Korea: incidence, mortality, survival, and prevalence in 2009. Cancer Res Treat 2012;44:11-24.

3. Matsuda A, Matsuda T, Shibata A, Katanoda K, Sobue T, Nishimoto H. Cancer incidence and incidence rates in Japan in 2008: a study of 25 population-based cancer registries for the Monitoring of Cancer Incidence in Japan (MCIJ) project. Jpn J Clin Oncol 2014:44:388-96.

4. Brenner H, Altenhofen L, Hoffmeister M. Sex, age, and birth cohort effects in colorectal neoplasms: a cohort analysis. Ann Intern Med 2010;152:697-703.

5. Ahlquist T, Lind GE, Costa VL, Meling GI, Vatn M, Hoff GS, et al. Gene methylation profiles of normal mucosa, and benign and malignant colorectal tumors identify early onset markers. Mol Cancer 2008;7:94.

6. Feagins LA, Souza RF, Spechler SJ. Carcinogenesis in IBD: potential targets for the prevention of colorectal cancer. Nat Rev Gastroenterol Hepatol 2009;6:297-305.

7. Becker C, Fantini MC, Schramm C, Lehr HA, Wirtz S, Nikolaev A, et al. TGF-beta suppresses tumor progression in colon cancer by inhibition of IL-6 trans-signaling. Immunity 2004:21:491-501.

8. Popivanova BK, Kitamura K, Wu Y, Kondo T, Kagaya T, Kaneko S, et al. Blocking TNF-alpha in mice reduces colorectal carcinogenesis associated with chronic colitis. J Clin Invest 2008; 118:560-70.

9. Bollrath J, Phesse TJ, von Burstin VA, Putoczki T, Bennecke M, Bateman T, et al. gp130-mediated Stat3 activation in enterocytes regulates cell survival and cell-cycle progression during colitis-associated tumorigenesis. Cancer Cell 2009;15:91-102.

10. Grivennikov S, Karin E, Terzic J, Mucida D, Yu GY, Vallabhapurapu S, et al. IL-6 and Stat3 are required for survival of intestinal epithelial cells and development of colitis-associated cancer. Cancer Cell 2009;15:103-13.

11. Corpet DE, Pierre F. How good are rodent models of carcinogenesis in predicting efficacy in humans? A systematic review and meta-analysis of colon chemoprevention in rats, mice and men. Eur J Cancer 2005:41:1911-22.

12. Papanikolaou A, Shank RC, Delker DA, Povey A, Cooper DP, Rosenberg DW. Initial levels of azoxymethane-induced DNA methyl adducts are not predictive of tumor susceptibility in inbred mice. Toxicol Appl Pharmacol 1998;150:196-203.

13. Tanaka T, Kohno H, Suzuki R, Yamada Y, Sugie S, Mori H. A novel inflammation-related mouse colon carcinogenesis model induced by azoxymethane and dextran sodium sulfate. Cancer Sci 2003:94:965-73.

14. Okayasu I, Hatakeyama S, Yamada $\mathrm{M}$, Ohkusa $\mathrm{T}$, Inagaki $\mathrm{Y}$, Nakaya R. A novel method in the induction of reliable experimental acute and chronic ulcerative colitis in mice. Gastroenter- ology 1990;98:694-702.

15. Ju J, Hao X, Lee MJ, Lambert JD, Lu G, Xiao H, et al. A gamma-tocopherol-rich mixture of tocopherols inhibits colon inflammation and carcinogenesis in azoxymethane and dextran sulfate sodium-treated mice. Cancer Prev Res (Phila) 2009:2:143-52.

16. Suzuki R, Kohno H, Sugie S, Nakagama H, Tanaka T. Strain differences in the susceptibility to azoxymethane and dextran sodium sulfate-induced colon carcinogenesis in mice. Carcinogenesis 2006;27:162-9.

17. Yum HW, Zhong X, Park J, Na HK, Kim N, Lee HS, et al. Oligonol inhibits dextran sulfate sodium-induced colitis and colonic adenoma formation in mice. Antioxid Redox Signal 2013;19:102-14.

18. Hamilton SR, Aaltonen LA. Pathology and genetics of tumours of the digestive system. Lyon, IARC Press, 2000.

19. Shaker A, Swietlicki EA, Wang L, Jiang S, Onal B, Bala S, et al. Epimorphin deletion protects mice from inflammation-induced colon carcinogenesis and alters stem cell niche myofibroblast secretion. J Clin Invest 2010;120:2081-93.

20. Yoshida Y, Wang IC, Yoder HM, Davidson NO, Costa RH. The forkhead box M1 transcription factor contributes to the development and growth of mouse colorectal cancer. Gastroenterology 2007;132:1420-31.

21. Thaker AI, Shaker A, Rao MS, Ciorba MA. Modeling colitis-associated cancer with azoxymethane (AOM) and dextran sulfate sodium (DSS). J Vis Exp 2012;(67):4100.

22. Neufert C, Becker C, Neurath MF. An inducible mouse model of colon carcinogenesis for the analysis of sporadic and inflammation-driven tumor progression. Nat Protoc 2007;2:1998-2004.

23. Zelinkova Z, van der Woude CJ. Gender and inflammatory bowel disease. J Clin Cell Immunol 2014:5:245.

24. Ishige $\mathrm{T}$, Tomomasa $\mathrm{T}$, Takebayashi $\mathrm{T}$, Asakura $\mathrm{K}$, Watanabe $\mathrm{M}$, Suzuki $\mathrm{T}$, et al. Inflammatory bowel disease in children: epidemiological analysis of the nationwide IBD registry in Japan. J Gastroenterol 2010;45:911-7.

25. Leong RW, Lau JY, Sung JJ. The epidemiology and phenotype of Crohn's disease in the Chinese population. Inflamm Bowel Dis 2004:10:646-51.

26. Yang SK, Loftus EV Jr, Sandborn WJ. Epidemiology of inflammatory bowel disease in Asia. Inflamm Bowel Dis 2001;7:260-70.

27. Yang SK, Yun S, Kim JH, Park JY, Kim HY, Kim YH, et al. Epidemiology of inflammatory bowel disease in the Songpa-Kangdong district, Seoul, Korea, 1986-2005: a KASID study. Inflamm Bowel Dis 2008; 14:542-9.

28. Bernstein CN, Blanchard JF, Rawsthorne P, Yu N. The prevalence of extraintestinal diseases in inflammatory bowel disease: a population-based study. Am J Gastroenterol 2001;96:1116-22.

29. Brahme F, Lindström C, Wenckert A. Crohn's disease in a defined population. An epidemiological study of incidence, prevalence, mortality, and secular trends in the city of Malmö, Sweden. Gastroenterology 1975;69:342-51.

30. Freeman HJ. Comparison of longstanding pediatric-onset and adult-onset Crohn's disease. J Pediatr Gastroenterol Nutr 2004; 39:183-6.

31. Griffiths AM. Specificities of inflammatory bowel disease in childhood. Best Pract Res Clin Gastroenterol 2004;18:509-23.

32. Kyle J. Crohn's disease in the northeastern and northern Isles of Scotland: an epidemiological review. Gastroenterology 1992;103: 392-9.

33. Latour P, Louis E, Belaiche J. Incidence of inflammatory bowel 
disease in the area of Liège: a 3 years prospective study (1993-1996). Acta Gastroenterol Belg 1998;61:410-3.

34. Shivananda S, Lennard-Jones J, Logan R, Fear N, Price A, Carpenter $\mathrm{L}$, et al. Incidence of inflammatory bowel disease across Europe: is there a difference between north and south? Results of the European Collaborative Study on Inflammatory Bowel Disease (EC-IBD). Gut 1996;39:690-7.

35. Sincić BM, Vucelić B, Persić M, Brncić N, Erzen DJ, Radaković B, et al. Incidence of inflammatory bowel disease in Primorsko-goranska County, Croatia, 2000-2004: a prospective population-based study. Scand J Gastroenterol 2006:41:437-44.

36. Van Gossum A, Adler M, De Reuck M, Devis G, Fiasse R, Vanheurverzwijn R, et al. Epidemiology of inflammatory bowel disease in Brussels' area (1992-1993). Acta Gastroenterol Belg 1996:59:7-9.

37. García-Gómez E, González-Pedrajo B, Camacho-Arroyo I. Role of sex steroid hormones in bacterial-host interactions. Biomed Res Int 2013;2013:928290.

38. Klein SL. The effects of hormones on sex differences in infection: from genes to behavior. Neurosci Biobehav Rev 2000;24:627-38.

39. Nussinovitch U, Shoenfeld $Y$. The role of gender and organ specific autoimmunity. Autoimmun Rev 2012;11:A377-85.

40. Jess T, Rungoe C, Peyrin-Biroulet L. Risk of colorectal cancer in patients with ulcerative colitis: a meta-analysis of populationbased cohort studies. Clin Gastroenterol Hepatol 2012;10:639-45.

41. Bewtra M, Kaiser LM, TenHave T, Lewis JD. Crohn's disease and ulcerative colitis are associated with elevated standardized mortality ratios: a meta-analysis. Inflamm Bowel Dis 2013;19:599-613.

42. Kim SE, Paik HY, Yoon H, Lee JE, Kim N, Sung MK. Sex- and gen- der-specific disparities in colorectal cancer risk. World J Gastroenterol 2015:21:5167-75.

43. Hansen IO, Jess P. Possible better long-term survival in left versus right-sided colon cancer: a systematic review. Dan Med J 2012;59:A4444.

44. Benedix F, Kube R, Meyer F, Schmidt U, Gastinger I, Lippert H. Comparison of 17,641 patients with right- and left-sided colon cancer: differences in epidemiology, perioperative course, histology, and survival. Dis Colon Rectum 2010;53:57-64.

45. Markowitz SD, Bertagnolli MM. Molecular origins of cancer: Molecular basis of colorectal cancer. N Engl J Med 2009;361:2449-60.

46. Jacobs ET, Thompson PA, Martínez ME. Diet, gender, and colorectal neoplasia. J Clin Gastroenterol 2007;41:731-46.

47. Missiaglia E, Jacobs B, D'Ario G, Di Narzo AF, Soneson C, Budinska $\mathrm{E}$, et al. Distal and proximal colon cancers differ in terms of molecular, pathological, and clinical features. Ann Oncol 2014:25: 1995-2001.

48. Slattery ML, Potter JD, Curtin K, Edwards S, Ma KN, Anderson K, et al. Estrogens reduce and withdrawal of estrogens increase risk of microsatellite instability-positive colon cancer. Cancer Res 2001;61:126-30.

49. Ritenbaugh C, Stanford JL, Wu L, Shikany JM, Schoen RE, Stefanick ML, et al. Conjugated equine estrogens and colorectal cancer incidence and survival: the Women's Health Initiative randomized clinical trial. Cancer Epidemiol Biomarkers Prev 2008:17:2609-18.

50. Brenner $\mathrm{H}$, Haug $\mathrm{U}$, Hundt $\mathrm{S}$. Sex differences in performance of fecal occult blood testing. Am J Gastroenterol 2010;105:2457-64. 